\title{
Book Review of "Palaeoseismology: historical and prehistorical records of earthquake ground effects for seismic hazard assessment"
}

\author{
F. Guzzetti \\ CNR IRPI, Perugia, Italy
}

\begin{abstract}
PALAEOSEISMOLOGY: HISTORICAL AND PREHISTORICAL RECORDS OF EARTHQUAKE GROUND EFFECTS FOR SEISMIC HAZARD ASSESSMENT, EDITED BY: KLAUS REICHERTER, ALESSANDRO M. MICHETTI AND PABLO G. SILVA, THE GEOLOGICAL SOCIETY, LONDON, GEOLOGICAL SOCIETY SPECIAL PUBLICATION NO. 316, 332 PAGES, ISBN10 1-86239-276-5, ISBN-13 978-1-86239-276-2, HARDBACK, PRICE $£ 90.00,2009$.
\end{abstract}

The Geological Society of London (GSL) has published several volumes on geological hazards, including earthquakes. An important addition to the GSL Special Publication collection is a recent multi-authored volume on palaeoseismology, a discipline that exploits geological information and knowledge to understand past earthquakes, and to improve our understanding of present and future seismic hazards. The book, edited by Klaus Reicherter, Alessandro Michetti and Pablo Silva, contains papers that address scientific and technical problems with the compilation and analysis of historical and pre-historical records of earthquake induced ground and environmental effects, for earthquake intensity mapping and seismic hazard assessment. The articles are the result of an editorial selection from oral and poster contributions presented at two international meetings held in the spring of 2006: (i) a session entitled "3000 years of earthquake ground effects reports in Europe: geological analysis of active faults and benefits for hazard assessment", held in Vienna, Austria, at the annual Assembly of the European Geosciences Union, and (ii) a workshop on "Seismic hazard analyses for critical facilities", which was jointly organized in Trieste, Italy, by the International Centre for Theoretical Physics and the International Atomic Energy Agency, with the co-sponsorship of the sub-commission on Palaeoseismicity of the International Union for Quaternary Research (INQUA).

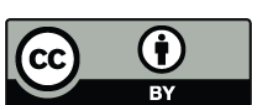

Correspondence to: F. Guzzetti

(fausto.guzzetti@irpi.cnr.it)
The three editors coordinated more than seventy authors that collectively produced eighteen papers reporting on recent, historic and prehistoric earthquakes and palaeoseismological studies in sixteen countries and in five continents. The recent and historical earthquakes discussed in the book occurred chiefly during the period from the 12th century to 2006, and covers the range of magnitudes between 4 and 8 , including the 2001 Kunlun $\left(M_{w}=7.8\right)$, China, the $2003 \mathrm{Al}$ tai $\left(M_{w}=7.6\right)$, Russia, the 2004 Chuetsu $\left(M_{w}=6.6\right)$, Japan, the 2005 Muzaffarabad, $\left(M_{w}=7.6\right)$, Pakistan, and the 2006 Kytira $\left(M_{w}=6.7\right)$, Greece, earthquakes. Both high to very high seismic areas in active tectonic systems - including the Mediterranean, the North Anatolian fault system, the Himalayas thrust and fold belt, Japan, Taiwan, and Central America - and areas where the present seismicity is moderate to low - e.g., Scandinavia, Germany, and the Gibraltar area - are considered.

In the first chapter of the book, the three editors present a concise description of the Environmental Seismic Intensity scale (ESI 2007) proposed by INQUA's sub-commission on Palaeoseismicity for measuring the intensity of earthquakes. The 12-degree intensity scale is similar to other earthquake intensity scales, including the Mercalli-CancaniSieberg (MCS), the Modified Mercalli (MM-31 and MM56), the Medvedev-Sponheuer-Karnik (MSK-64), and the European Macroseismic (EMS-98) scales. A significant difference consists in the fact that the ESI 2007 scale aims at evaluating the size (intensity) of an earthquake solely from an ensemble of earthquake-related environmental effects not conditioned by human factors (e.g., population density, building types, quality and abundance). Considered environmental effects include primary (i.e., fault surface rupture, tectonic uplift or subsidence) and secondary (i.e., ground fractures, landslides, liquefaction processes, tsunamis and other anomalous water waves, hydrological anomalies, tree shaking) effects.

Published by Copernicus Publications on behalf of the European Geosciences Union. 
According to the authors, the ESI 2007 scale is not meant to replace the other scales. It is intended to consider in macroseismic investigations environmental effects caused by earthquakes on the natural environment, to obtain an improved and more informative estimate of the seismic intensity and its geographical pattern and extent.

In this volume, a number of applications of the ESI 2007 scale in different geological settings and tectonic regimes are presented, including discussions of the advantages and problems encountered, and comparisons with other earthquake intensity scales. The other chapters address multiple and partly overlapping topics, including the assessments of the earthquake (seismic) history in relation to the regional and local tectonic and geologic settings, and the application of geophysical, archaeological and speleological techniques for improved macroseismic analysis.

Although the book does not cover the full range of macroseismic and palaeoseismological research - this would have been an unrealistic ambition for a single volume - it provides a good overview of the scopes, techniques, methods and expected results of modern macroseismic studies and palaeoseismology. A limitation of the volume - and of individual chapters - exists because the direct application of palaeoseismology for seismic hazard evaluation remains limited. The individual articles are generally well written and clearly illustrated with numerous colour photographs, diagrams and maps. In a few cases, language is not consistent or precise. In this respect, the volume lacks homogeneity, a result of the complexity, diversity and breath of an evolving discipline.

The volume is well produced and offered at a reasonable price. It provides valuable new data and information, and promotes the use of the Environmental Seismic Intensity scale (ESI 2007) for measuring earthquake intensity. For these reasons, I recommend it for public and personal libraries. 